\title{
What Do We Know About Vision?
}

Sooksan Kantabutra, Mahidol University, Bangkok, Thailand

\begin{abstract}
Given the criticality of vision to leadership, the paucity of research into vision is surprising. This paper reviews the theoretical and empirical literature on vision, highlighting early concepts of vision, vision definitions and components before proposing future research directions, including looking at what the components of an "effective" vision are, identifying the attributes and content of visions associated with desirable performance and ability to sustain it.
\end{abstract}

\section{INTRODUCTION}

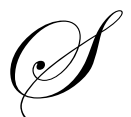

ince the 1980s, the focus on leadership has shifted from traits and leader behaviors to the need for leaders to articulate visions to their followers, particularly those in organizations undergoing major change (e.g. Bass, 1990; Conger, 1991; Conger \& Kanungo, 1987; Lucey, Bateman \& Hines 2005). Shared vision also is said to be fundamental to network organizations of the future (Avery, 2004). In the changing context, vision refers to a cognitive image of a desired future state (Bennis \& Nanus, 1985). It has alternated from being construed as a faddish and trendy concept, to being viewed as a fundamental attribute of effective leadership and a basis of one's power to lead (e.g. Kouzes \& Posner, 1987; Zaccaro \& Banks, 2004). Clearly, the importance of vision has been emphasized by leadership scholars in both theoretical discussions (e.g. Maccoby, 1981; Peters, 1987; Slater, 1993) and research (e.g. Kotter 1990; Larwood et al., 1995; Westley \& Mintzberg, 1989). In particular, researchers (e.g. Hamel \& Prahalad, 1989) have asserted that an organization with a well-articulated vision can achieve sustained competitive advantage over those organizations lacking such a vision. Time and time again, if a corporate leader is successful, his or her vision is cited as the cause and lauded as the foundation of the leader's greatness (Humphreys, 2004).

Given the criticality of vision in the leadership literature, the purpose of this paper is to identify the current knowledge about vision through a review of the theoretical and empirical literature. It starts with a theoretical background on early concepts of vision, vision definitions, and then vision components, followed by relevant empirical evidence. Finally, future research directions are proposed to advance our knowledge about vision.

\section{THEORETICAL BACKGROUND}

In this section, early concepts of vision, the theoretical literature on vision definitions, attributes and content is discussed, followed by a review section of the empirical literature.

\section{Early Concepts of Vision}

Since charisma and vision concepts are closely related in the literature, it is unavoidable to discuss both in tracing back early concepts of vision. Charisma is a Greek word which means "divinely inspired gift" (Gove \& Webster, 1993). This "divinely-inspired gift" is, for example, an ability to perform miracles or predict future events. The sociologist Max Weber (1947) used charisma as a term to describe a form of influence which is not based on tradition or formal authority, but rather on follower perceptions that the leader is endowed with exceptional qualities. Weber pointed out that charisma occurs during a social crisis in which a leader with exceptional personal qualities emerges with a radical vision that provides a solution to the crisis and attracts followers who believe in the vision and perceive the leader to be extraordinary.

While Plato's view of leadership was that a leader must be a man of power with a sincerely-truth-seeking vision (Takala, 1998), his point of view comes close to that of Weber because the Weberian concept of charisma is 
that a charismatic leader is self-ordained and self-styled with a "mission" which claims that his action is his destiny (Weber, 1947). Plato asserted that a leader must have charisma, the gift of grace, to be successful in his actions (Takala, 1998). In Plato's view, charisma is so important that, without it, a leader is not able to do his job, to be the head of a group. According to Plato, charisma is mystical and cannot be obtained by force of training (Takala, 1998). It is of divine origin.

"Charisma" and "vision" were long introduced in religious and political leadership. Espousing a vision within religious institutions is common (Thomas \& Thomas, 1959). Mohammed and Jesus Christ are two examples of a religious leader who had a powerful "vision". What is particularly important about them is the "vision" they shared with their followers (Thomas \& Thomas, 1959; Viney, 1999). Both offered people a new and radical belief system. Jesus offered forgiveness of sins, life ever after, and everlasting love from his God (Thomas \& Thomas, 1959). Mohammed's "vision" made the Arab God's standard-bearer on earth (Thomas \& Thomas, 1959; Viney, 1999). The role of the devil was significantly reduced, and followers could look forward to a heaven, a very sensual place. By communicating their visions, Jesus and Mohammed offered people hope, a sense of aspiration, a sense of certainty, and a sense of being special (Thomas \& Thomas, 1959). There is little wonder that their visions have been immensely portable. Islam moved far beyond the Arab people and traveled to Asia (Thomas \& Thomas, 1959; Viney, 1999), while Christianity also traveled to many parts of the world (Adair, 1989; Thomas \& Thomas, 1959; Viney, 1999). Obviously, both Jesus's and Mohammed's visions inspire followers across many different cultures, although they operated quite locally in their lifetimes.

In the political arena, the writer of Proverbs asserted several thousand years ago that vision is critical to people's live (Stevenson, 1949; Wallis, 1994). Alexander the Great is a good example of a political leader with a vision. With his vision of conquering the world, he showed the way ahead, held the Greek army of some 30,000 foot soldiers together as a group, and encouraged individuals by example and word to keep going, notwithstanding the hardships and dangers of travel (Adair, 1989). Later on, no one would dispute the transformational power of visionary, political leaders such as Adolf Hitler, Abraham Lincoln, Mahatma Gandhi, and Nelson Mandela (Adair, 1989). These political leaders have inspired their followers to work toward their visions.

Before the 1980s, vision was mostly a concept of researchers who studied political leadership, and the leadership of social or religious movements. It was rarely considered within the leadership literature. Only in the past couple of decades has vision been extensively discussed in the leadership discipline. In this context, the use of vision has been widely exhorted as one of the main characteristics of "effective" leaders (e.g. Bass, 1985; Bryman, 1992; Conger \& Kanungo, 1987; Humphreys, 2004). The leader creates a picture of a future world, which is frequently referred to as a vision (e.g. Hamburger, 2000). He/she then inspires his/her followers by communicating a positive and attractive image of the future, lifting people out of day-to-day existence and putting meaning into their lives (Hamburger, 2000). Not only is vision an idea or image of a desirable future, but the right vision can also actually jump-start the future by mobilizing people into action toward achieving it (Nanus, 1992). The motivational value of a clearly-articulated vision comes mainly from the sense of broader purpose and meaning that the vision provides. One observation here is that both the business vision concepts and those in the political and religious leadership share the notion that leaders attempt to influence and engage their followers through his/her desired future state, still to a large extent a top-down approach to leadership.

There is no doubt however that many leadership scholars have seen vision as important to leadership, strategy implementation, and change (Collins \& Porras, 1994; Doz \& Prahalad, 1987; Humphreys, 2004; Hunt, 1991; Kotter, 1990; Robbins \& Duncan, 1988; Sashkin, 1988). Although some managers dismiss visions as irrelevant to organization performance (see Rynes, Colbert \& Brown, 2002), businesses need a purpose (Avery, 2005). Supporting this view, Handy (2002) argues that the purpose of a business goes beyond making a profit, to something "better", a higher-level purpose. Bryman (1992) argues that charismatic leaders have a vision or a higherorder purpose that they are capable of communicating to their followers in such as way as to ensure that followers will enthusiastically commit themselves to it. The leader's role then is to empower people to carry out the vision, and to structure the organization and its culture according to the vision. In trying to integrate the fragmented field of Leadership, Avery (2004) names a paradigm of leadership "Visionary Leadership", in which a leader espouses a 
vision to bring about superior performance outcomes through involving follower emotional commitment to the vision. This underlines the important role that vision plays.

The early concepts of vision in both political and religious leadership suggest a new sense of direction, and often involve a transformation of a group of followers, similar to the concepts of contemporary vision in the leadership literature. In political, religious and business leadership, where the top-down approach to management can be found, vision is developed and used by a leader to inspire followers to work toward a common goal.

\section{Vision Definition}

Despite its obvious importance, vision is still not defined in a generally agreed upon manner, which is critical because empirical research on vision may be affected by the various ways in which vision has been defined. Moreover, practitioners may also be confused as to which definition to adopt. Hunt (1991) and Sashkin (1988) suggest that vision is a form of leadership in which a visionary leader transforms an organizational culture to bring organization members to understand, accept and carry out his/her plan for the organization. Quite differently, Pearson (1989) and Phillip and Hunt (1992) have viewed vision as one of the required tasks top managers perform. Sashkin (1992) later on have viewed vision as a demonstration of leadership competencies. Considerable disagreement also exists over whether terms like mission, goals, core values, strategy, and organizational philosophy differ from vision. For example, much confusion exists between vision and mission. In an educational setting, Hallinger and Heck (2002) pointed out that an organizational mission is indeed a vision shared by organizational members. According to them, mission or shared vision exists when personal visions of a critical mass of people cohere in a common sense of purpose within a community. Here, vision is a purpose. On the other hand, Levin (2000) suggested that mission instead provides a statement of the purpose of an organization's existence, while vision is a statement of direction. Endorsing Levin's view, O'Brien and Meadows (2000) concurred that mission is a statement of purpose, although others prefer to define mission as an often-inseparable component of a business' vision. Lipton (1996), among others, defined vision as a combination of mission, strategy, and culture. In Lipton's view, mission was defined as the purpose of an organization, strategy as a basic approach to achieving the mission, and culture as the values of an organization that support purpose and strategy. Collins and Porras (1994) suggested two different components of vision: "core identity" and "envisioned future." To them, a good vision builds on the interplay between these two complementary forces. The vision defines "what we stand for and why we exist" that does not change (the core ideology) and sets forth "what we aspire to become, to achieve, to create" that will require significant change and progress to attain (the envisioned future). Therefore, a vision here indicates both purpose and direction.

Adopting a different view, other scholars stated that vision needs to come first in order to subsequently drive development of mission and strategy (e.g. Hay \& Williamson, 1997; Parikh \& Neubauer, 1993; Zaccaro \& Banks, 2004). Therefore, vision, mission and strategy are three separable components. In addition to the confusion between mission and vision, vision is also seen as closely related to organizational goals and strategy (e.g. Levin, 2000; Schoemaker, 1992).

Philosophy and vision are also frequently confounded, probably because both are inspirational and idealistic. However, Levin (2000) argued that visions should go well beyond statements of philosophy by describing those values and ideals in action, including a description of how these ideals are practiced, what that experience is like for those affected, and a link between these preferred behaviors and successful performance. It seems that a vision here paints a picture of how it looks like and feels like when a vision is attained. Therefore, as opposed to many concise vision statements preferred by other scholars (e.g. Locke et al., 1991), Levin's notion of vision provides for more lengthy vision statements.

From a view of New Science that means exciting breakthroughs especially in quantum physics that are overturning centuries-old, Newtonian models of science, Wheatley (1999) suggested that vision is a field which leaders can use as a formative influence. Creating a vision means creating a power, not a place; an influence, not a destination. This field metaphor would help leaders to understand that they need congruency by matching visionary messages with visionary behaviors. Leaders also would know that vision must permeate through an entire 
organization as a vital influence on the behavior of all stakeholders. Leaders would also feel genuinely threatened by incongruous acts, because leaders would understand their disintegrating effects on what they dream to accomplish. Their organization would become an organization of integrity, where their words would be translated into action.

Despite the definitional confusion, a comparison of the various definitions of vision suggests that they share a similar set of characteristics (see Table 1). Essentially, scholars agree that vision is about the future, induces people to act towards a common goal, provides a sense of direction, and is important for strategy and planning. Regardless of these commonly shared characteristics resulting from attempts to define vision, there is little agreement among academics as to what "vision" is. The situation does not appear very different among practitioners, as they are equally confused with the titles of mission, vision, values, beliefs, principles and strategic intent/ direction (Baetz \& Bart, 1996). Raynor (1998) suggested that these concepts are so tied together that to speak of one was to involve them all. Van der Heijden (1996) introduced the term "Business Idea", possibly as a way out, which he defined as an organization's mental model of forces behind its current and future success.

\begin{tabular}{|c|c|c|}
\hline $\begin{array}{r}\text { Item } \\
\text { No. }\end{array}$ & Shared Characteristics & Theorists \\
\hline 1 & $\begin{array}{l}\text { Vision is always about a desirable } \\
\text { future. }\end{array}$ & $\begin{array}{l}\text { e.g. Collins \& Porras, 1994; Kotter, 1997; } \\
\text { Lipton, 1996; Sashkin, 1988, 1992; } \\
\text { Senge, } 1990\end{array}$ \\
\hline 2 & $\begin{array}{l}\text { Vision is considered as necessary } \\
\text { for leadership, a process of } \\
\text { inducing others to act toward a } \\
\text { common goal. }\end{array}$ & $\begin{array}{l}\text { e.z. Benris, 1990; Locke et al., 1991; Phillips } \\
\text { \& Hunt, 1992; Quigley, 1993; Sashkin, 1992; } \\
\text { Wheatley, } 1999\end{array}$ \\
\hline 3 & $\begin{array}{l}\text { Vision provides a sense of } \\
\text { direction for organizational } \\
\text { members to proceed. }\end{array}$ & $\begin{array}{l}\text { e.g. Collins \& Porras, 1994; Davis \& Meyer, } \\
\text { 1998; Hunt, 1991; Jacobs \& Jaques, 1990; } \\
\text { Kotter, 1997; Levin, 2000; Lipton, 1996; } \\
\text { Sashkin, 1988, 1992; Seeley, 1992; } \\
\text { Senge,1990 }\end{array}$ \\
\hline 4 & $\begin{array}{l}\text { Wision is seen as important for } \\
\text { business strategy and planning. }\end{array}$ & $\begin{array}{l}\text { e.g. Collins \& Porras, 1994; Hay \& } \\
\text { Williamson, 1997; Parikh \& Heubauer, 1993; } \\
\text { Schoemaker, 1992; Senge, 1990; } \\
\text { Vandermerwe, 1995 }\end{array}$ \\
\hline
\end{tabular}

Table-1: Commonly Shared Vision Characteristics

Taking a pragmatic approach to resolve the definitional confusion, Baum, Locke and Kirkpatrick (1998) chose to define the term vision as each leader defines it, because it is the leader's actual vision that guides his/her choices and actions. However, it appears that Baum et al. (1998) adopted the top-down approach to leadership in defining a vision. Baum et al.'s (1998) definition might not be practical in networked organizations of the future, in which vision emerges from all organizational members (Avery, 2004). Indeed, the focus on vision has shifted from a vision as proclaimed by a single central leader to a vision as proclaimed by all organizational members. Avery (2004) provides a reason for this by suggesting that a vision developed by a leader may not be the most effective as the business environment becomes more heterogeneous, highly complicated and dynamic. In the past where a business was locally defined and predictable, a vision from the traditional single leader was enough to provide a "right" direction. In such a dynamic and unpredictable context, leadership will need to operate more through vision and values permeating the culture (Avery, 2004), which will become or replace the single guiding vision (Drath, 1998). In this environment, each member of the organization shares the vision and values, being able to respond effectively, innovatively and timely to environmental changes. Avery (2005) also asserts that leaders that espouse a vision will be able to sustain their corporate performance in the long run. 
More appropriately dealing with the definitional issue and the changing context, Mumford and Strange (2005) suggest that vision is ultimately a cognitive construction or specifically a mental model, a conceptual representation used to both understand system operations and guide actions within the system. I agree with Mumford and Strange's vision definition because a vision, defined as a mental model, can accommodate both the top-down and bottom-up approaches to leadership.

\section{Vision Attributes}

Senge (1990) argues that two types of vision exist: positive and negative visions. According to Senge, a positive vision emphasizes change and aspirations for growth, while a negative vision emphasizes continuing the status quo, even under changing environments. Despite the diverging views on how to define a vision, many leadership scholars appear to agree with Senge by providing different attributes seen to be necessary for a vision to be "positive". Among various opinions, Locke et al. (1991) view that an effective vision is inspiring, abstract, brief, stable and motivating. On the other hand, Conger (1989) suggests that an effective vision is strategic and wellcommunicated while Kouzes and Posner (1987) and Jacobs and Jaques (1990) assert that long-term and focus should be included. Sashkin (1988) and Sims and Lorenzi (1992) proposed that effective visions are inspirational, widely accepted, and integrated with visions of others. A large group of scholars also argues that an effective vision should have clarity, because the degree of clarity or precision of the vision statement influences how well the vision is understood and accepted (e.g. Jacobs \& Jaques, 1990, Locke et al, 1991; Nanus, 1992; Sashkin, 1988; Sims \& Larenzi, 1992). Concurring with this view, Nanus (1992) suggested that effective visions should be clearly understood and act to direct effort. Other scholars have posited that effective visions should be inspiring and challenging to energize employees around a shared value system (Locke et al, 1991; Sashkin, 1988; Sims \& Lorenzi, 1992).

Though many leadership theorists have postulated different attributes of vision, there are some commonly shared attributes among them, as shown in Table 2, which includes definitions derived from Baum (1994), Baum et al. (1998) and Locke et al. (1991) who are among a few scholars studying the commonly shared vision attributes.

\begin{tabular}{|c|l|l|}
\hline $\begin{array}{c}\text { Item } \\
\text { No. }\end{array}$ & $\begin{array}{c}\text { Shared } \\
\text { Attributes }\end{array}$ & \multicolumn{1}{c|}{ Definitions } \\
\hline 1 & Brevity & $\begin{array}{l}\text { A vision statement should be brief, but brevity should not overnule the endeavor to } \\
\text { state the vision de finitely. }\end{array}$ \\
\hline 2 & Clarity & $\begin{array}{l}\text { A vision statement should be clear and precise in such a way that it is understood } \\
\text { and accepted. Clarity makes the overarching goals understandable to everyone. }\end{array}$ \\
\hline 3 & $\begin{array}{l}\text { Future } \\
\text { orientation }\end{array}$ & $\begin{array}{l}\text { A vision statement should focus on the long-term perspective of the organization and } \\
\text { the environment in which it functions. It should guide the organization far into the } \\
\text { future. }\end{array}$ \\
\hline 4 & Stability & $\begin{array}{l}\text { A vision statement should be general and abstract enough that it is not affected by } \\
\text { most of the changes in the market or in technology. }\end{array}$ \\
\hline 6 & Challenge & $\begin{array}{l}\text { A vision statement should motivate people to work toward a desirable outcome. } \\
\text { Visions challenge people to do their best. }\end{array}$ \\
\hline 7 & $\begin{array}{l}\text { Desirability } \\
\text { or ability to } \\
\text { inspire }\end{array}$ & $\begin{array}{l}\text { A vision statement should represent an ideal that is worth working toward for the } \\
\text { followers. If followers do not perceive the vision as an attractive goal, they will } \\
\text { never commit themselves to achieving it. }\end{array}$ \\
\hline
\end{tabular}

Table-2: Vision Attributes 
Although vision is emphasized as a core issue in the prevailing vision-based leadership theories (Bass, 1990; Conger, 1989; Conger \& Kanungo, 1987; Tichy \& Divanna, 1986; Westley \& Mintzberg, 1989), and many characteristics of effective vision have been introduced, none of the prevailing theories has exhaustively explained how each characteristic might create an impact on organizational performance. In his effort to develop a vision theory to fill in the gap, Kantabutra (2003) asserted that the seven vision attributes mentioned above interact to create a positive impact on overall organizational performance initially through follower satisfaction. A vision that is too brief will not positively impact overall organizational performance unless it is clear to followers what needs to be done, or it may not appear to challenge followers to do their best. A clear vision will not positively influence follower satisfaction because it may be too lengthy, preventing a leader to communicate it massively and frequently. It also may be too abstract, therefore possibly creating conflicts among groups with different specific purposes and not allowing for individual creative interpretation among followers. A too specific vision makes it difficult to form an effective group to carry out the vision. Moreover, abstractness reflects stability in the vision because it implies no radical change over time. An unstable vision suggests to followers a serious lack of managerial integrity and commitment to the vision, negatively affecting follower morale. A vision that is brief, clear, abstract, challenging and stable will not draw follower commitment in working toward the vision unless the vision is also inspiring or desirable. In addition, when a vision is not inspiring or desirable, it is unlikely to develop and nurture a shared vision, which is critical to organizational performance. An inspiring vision that is clear, brief, abstract, challenging, and stable will not be able to attract affective commitment from followers unless it offers a compelling view of a better future. Without a desirable future picture, a leader is unlikely to be able to draw followers from where they presently are to work toward the vision. Therefore, vision characterized by the seven vision attributes can improve the vision's effectiveness.

\section{Vision Content}

Literature on vision content is sparse. Andrews, Boyne and Walker (2006) draw from their study of one hundred and nineteen English local authorities to suggest that measures of strategy content must be included in valid theoretical and empirical models of organizational performance in the public sector because strategy content impacts organizational performance. Baum et al. (1998) argued that the content or core of a vision needs to be addressed because it is important to organizational growth. In a healthcare context, Williams-Brinkley (1999) argued that the focus of a healthcare vision should always be on patients, their families, and staff. In a public school setting, Kantabutra (2005a) argued that vision content should contain reference to teacher and student satisfaction, student achievement, and efficiency. Kantabutra (2005b) also argues that a vision should contain reference to corporate sustainability for a corporation to succeed in the long run. To be specific, such vision content should contain reference to moderation, reasonableness, the need for 'self-immunity' mechanisms, knowledge and morality to be able to sustain a business (Kantabutra, 2006).

A possible reason for the existence of many vision content proposals is that what should be included in vision content depends on the types of business and competitive environments in which they operate. If there is indeed common vision content across organizations, whether and how organizations can be developed, compete and sustain their strategic advantage are in a serious doubt. Scholars appear to agree with this conclusion. For example, Westley and Mintzberg (1989) suggest that the strategic content of a vision may focus on products, services, markets, organizations, or even ideals, with this strategic component being the central image that drives the vision. Moreover, Collins and Porras (1994) suggest that vision content need not be common across different visionary organizations. This is consistent with Pearson's view (1989) that a successful vision takes into account industry, customers, and the specific competitive environment in identifying an innovative competitive position in the industry.

In conclusion, what should be included in vision content depends on how a business wants to position itself strategically, given that vision is ultimately defined as a cognitive construction or mental model used to both understand system operations and guide actions within the system (Mumford \& Strange, 2005). This proposed vision definition appears to gain support from Westley and Mintzberg (1989) who suggest that vision process and content are blended together in accounts of visionary leadership. Though vision content and process, and visionary leadership, are distinctly different, it is clear that these aspects relate to one another in some complex ways. In 
theory, an effective vision should also be brief, clear, abstract, future oriented, stable, challenging and desirable or inspiring because these characteristics can enhance vision's effectiveness.

\section{EMPIRICAL BACKGROUND}

Overall, research has demonstrated significant contributions of visions to organizational effectiveness (Zaccaro, 2001). Lack of vision also appears to be associated with failed attempts to manage organizational change (e.g. Collins \& Porras, 1994; Lucey, Bateman \& Hines, 2005) and attention to vision was found to be a key strategy employed by 90 leaders who enlisted others in a common vision (Bennis \& Nanus, 1985). Visions offer a valuebased direction for the company and provide a rationale for strategic decision-making. While most of the previous research into vision was conducted at the individual level, as opposed to the level of the business-unit or organization-level, vision has been studied as a blend of charismatic leadership in a wide variety of samples and industries, with generally positive findings between this kind of leadership and followers' performance, attitudes, and perceptions.

Previous empirical studies range from laboratory subjects using students (e.g. Howell \& Frost, 1989; Kirkpatrick, 1992; Puffer, 1990), military leaders (e.g. Curphy, 1990; Yukl \& Van Fleet, 1982), national leaders (e.g. Bass, Avolio \& Goodheim, 1987; House, Spangler \& Woycke, 1991), corporate leaders (e.g. Baum et al., 1998; Bennis \& Nanus, 1985; Kantabutra, 2003), educational leaders and administrators (e.g. Roberts, 1985; Roberts \& Bradley, 1988; Sashkin 1988), to hospital leaders (e.g. Bryant, 1990; McDaniel \& Wolf, 1992). In addition, no published studies have reported a negative or non-significant relation between charismatic leadership and individual performance, possibly because negative or non-significant findings are rarely published.

Not only is vision found to be associated with bringing about competitive performance, it is also found to be critical to sustaining it. Avery (2005) discovered that vision is important to sustainable enterprises. It was found that European sustainable enterprises adopted the long-term perspective in managing their enterprises. This longterm perspective allows the organizations more time for a vision to be communicated and take effect. Another possible explanation for the impact of vision on corporate sustainability is that espousing a vision provides a cognitive map that underpins how resources are to be used and combined within the organization (Avery, 2004). To that extent, the vision channels organizational competencies in the direction of the organization's goals, which takes time. Avery (2005)'s research also pointed out that although all sustainable enterprises in her study had a vision, not all have articulated vision statements. For example, BMW did not have an explicit vision statement for many years. Rather, the vision appeared to stem from the brand. The BMW brand drives employees to maintain the high quality and excellence associated with it. This finding also supports the proposed vision definition of a cognitive construction or mental model that guides organizational actions discussed above.

Research on vision itself has generally focused on four aspects: development, articulation, communication, and implementation (e.g. Nanus, 1992; Quigley, 1993; Robbins \& Duncan, 1988; Sashkin, 1992; Wall, Solum \& Sobol, 1992; Westley \& Mintzberg, 1989). Little is known about what constitutes an effective vision. Baum et al. (1998) were among the first who found positive relationships between vision attributes of brevity, challenge, future orientation, aspiring, abstractness, clarity, stability and vision content, and organizational performance in entrepreneurial firms. The researchers surveyed CEOs of architectural woodwork firms, and found that vision attributes and vision content were directly related to venture growth, as measured by sales, profits, employment, and net worth in these entrepreneurial firms. These vision attributes were strongly related to venture growth through their effects on vision communication. Visions characterized by the attributes of brevity, clarity, abstractness, challenge, future orientation, stability, and desirability or ability to inspire have also been found to indirectly relate to customer satisfaction and directly relate to staff satisfaction in Australian apparel retail stores (Kantabutra, 2003). Findings from the two studies appear to endorse Kantabutra (2003)'s proposed theory of vision that the seven attributes interact to improve vision's effectiveness.

Similarly, empirical evidence on vision content is scanty. Larwood et al. (1995) published the first large sample empirical study of vision content. In this study, chief executives in one national and three regional samples participated in a study of content and structure of their business visions. They were asked to describe their visions in 
one sentence and to evaluate their visions along twenty-six content dimensions. Vision content ratings appeared in clusters found to relate to rapidity of firm change, amount of control the executives exercised over firms, and type of industry. The study did not, however, associate vision content with performance, a critical missing piece. Later on, Kirkpatrick and Locke (1996) found that vision statements that emphasized product quality were related to increased trust, leader-follower goal congruence, and inspiration. In a recent study by Dvir, Kass and Shamir (2004), vision formulation, content of social-oriented values, and assimilation were positively related to affective commitment to the organization, and unrelated to continuance commitment among one hundred and eighty three high-tech employees. This finding indicates the positive relationships of a balanced transcendental and realistic content of the vision and a high level of "sharedness" in vision assimilation processes to affective organizational commitment. This makes sense because people need to know where they need to head from the vision content before they agree with the direction and commit to it.

In Australia, Kantabutra (2003) found that store manager visions containing reference to customer and staff satisfaction were significantly correlated to customer and staff satisfaction in Australian apparel stores. Sales, customer, employee and leadership were four frequently mentioned vision content elements in this study, which is not surprising because all are strategically important to acquire or maintain a leadership position in the market. Moreover, Rafferty and Griffin (2004), drawing upon their study of a large Australian public sector organization, suggest that visions do not always create a positive impact on follower attitudes, and that one should distinguish between "strong" and "weak" visions as well as vision content to see their effectiveness. This suggestion gains support from Senge's (1990) view of negative and positive visions discussed earlier.

Given a wide range of what to be included in a vision in the theoretical literature, it is interesting to find that some of the best visions were not brilliantly innovative and all too often had an almost mundane quality, usually consisting of ideas that are already well-known (Kotter, 1999). This finding suggests that there may be a limitation to effective vision content. In addition, the seven vision attributes and vision content are related in some sophisticated ways. For example, for a vision to be challenging and inspiring, the vision's content must contain challenging and inspiring references. Similarly, for a vision to be abstract, its content must be very broad so that it could cover all organizational interests. When a vision suggests such a broad meaning, it often becomes very simple. This might be an answer to why successful visions regularly had an almost mundane quality, usually consisting of ideas that are already well-known (i.e. to be the world's leader, to be the best, to be the leading).

Another widely discussed assertion about vision is that vision must be shared between leader and followers to bring about superior performance outcomes, which has supporting empirical evidence. Kantabutra and Avery (2005) found that visions characterized by the attributes of brevity, clarity, stability, abstractness, future orientation, challenge, desirability and ability to inspire, and containing customer and staff satisfaction imagery, when shared by leader and followers, were correlated with enhanced organizational performance as measured by customer and staff satisfaction. Interestingly, shared visions directly created a positive impact on overall organizational performance through customer and staff satisfaction, taking into account manager efforts at empowerment and motivation, and staff use of vision to guide daily operations. Indeed, shared vision is inherent in staff performance, therefore creating an impact on customer satisfaction. More recently, Avery (2005) reported that there is plenty of evidence that shared vision, values and corporate philosophy operating among sustainable enterprises in Europe. This evidence underlines a role of vision in ensuring long-term organizational success.

In terms of realizing vision, Kantabutra (2003) found that visions characterized by the seven attributes of brevity, clarity, stability, abstractness, future orientation, challenge, desirability and ability to inspire played a significant role in realizing vision in Australian apparel retail stores. Using such vision, retail store managers could improve the effectiveness of their vision communication and attempts to motivation, empowerment and organizational alignment.

One mystery about vision is how people form viable visions. Among a very few researchers, Mumford and Strange (2005) found that vision formation requires descriptive models, reflection, and abstraction of key goals and/or key causes. Moreover, they also concluded that visioning involves a prescriptive model constructed through reflection and abstraction, and that visioning and planning should be treated as distinct constructs. 
Supporting the theoretical literature, the empirical review reveals that vision is still critical to broader organizational success and sustainability. However, there are few reported studies on the critical components of effective visions and/or how such visions are formed. These few studies nevertheless indicated positive relationships between vision attributes and content, and organizational performance, supporting the previously discussed theoretical literature that "effective" visions are critical to organizational success. It also appears that the vision attributes findings lend support to Kantabutra's (2003) proposed Vision theory.

\section{CONCLUSIONS \& FUTURE RESEARCH DIRECTIONS}

The literature review suggests that vision has been critical to managing people to achieve a goal since the antiquity. Although the concept of vision has its critics, the empirical review suggests that effective visions do make a positive impact on performance outcomes in practice, directly and/or indirectly. Vision will continue to play a critical role in improving and sustaining organizational performance, despite the trend that the approach to leadership seems to shift from top-down to bottom-up. Given the definitional confusion and need to define vision for researchers and practitioners, I agree with Mumford and Strange that vision is ultimately defined as a cognitive construction or specifically a mental model, a conceptual representation used both to understand system operations as well as guide actions within the system.

Our knowledge on what an effective vision looks like and thus how such vision is formed is still limited. The literature suggests two components of vision: attributes and content. An attempt has been made to develop a vision theory, proposing that effective visions are brief, clear, stable, challenging, future-oriented, desirable or inspiring, and abstract. This proposed vision theory appears to have broad support from the empirical literature. Similarly, our knowledge on the content of effective visions appears scanty. However, unlike vision attributes, there may not be a standard for vision content since vision content is strategic, depending on the type of business and its specific competitive environment.

Clearly, the literature suggests many areas for future vision research, including looking at what a vision is; the components of an "effective" vision are, identifying the attributes and content of visions associated with competitive performance. This is essentially a critical area for both academics and practitioners that we know so little about. Accordingly, the following propositions are advanced for future research to further enhance our understanding about vision.

Proposition 1: Visions that bring about desirable performance outcomes and ability to sustain them are cognitive constructions or specifically mental models, conceptual representations used both to understand system operations and guide actions within the system.

Proposition 2: Visions characterized by the seven vision attributes bring about better performance outcomes and ability to sustain them than those not characterized by the seven vision attributes. The seven attributes interact to create the results.

Proposition 3: Visions containing strategic references bring about better performance outcomes and ability to sustain them than those not containing strategic references. These strategic references usually consist of ideas that are already well known.

Propositions 4: Visions characterized by the seven vision attributes and containing strategic references bring about better performance outcomes and ability to sustain them than those not characterized by the seven vision attributes and containing strategic references. Both vision attributes and content interact to create such results. 


\section{REFERENCES}

1. $\quad$ Adair, J. (1989) Great Leaders. England: Talbot Adair Press.

2. $\quad$ Andrews, R., Boyne, G.A. \& Walker, R.M. (2006) Strategy content and organizational performance: An empirical analysis, Public Administration Review 66(1), 52-63.

3. Avery, G.C. (2005) Leadership for Sustainable Futures. Northampton, MA: Edward Elgar.

4. $\quad$ Avery, G.C. (2004) Understanding Leadership. London: Sage.

5. Baetz, M.C. \& Bart, C.K. (1996) Developing mission statements which work, Long Range Planning 29, 526-533.

6. $\quad$ Bass, B.M. (1985) Leadership and Performance Beyond Expectations. New York: Free Press.

7. Bass, B.M. (1990) Bass \& Stogdill's Handbook of Leadership: Theory, Research, \& Managerial Applications $\left(3^{\text {rd }}\right.$ ed.). New York: Free Press.

8. Bass, B.M., Avolio, B.J., \& Goodheim, L. (1987) Biography and the assessment of transformational leadership at the world class level, Journal of Management, 13, 7-19.

9. Baum, I.R., Locke, E.A. \& Kirkpatrick, S.A. (1998) A longitudinal study of the relation of vision and vision communication to venture growth in entrepreneurial firms, Journal of Applied Psychology, 83, 4354.

10. Baum, J.R. (1994) The Relations of Traits, Competencies, Vision, Motivation, and Strategy to Venture Growth, Doctoral dissertation, University of Maryland.

11. Bennis, W. (1990). Managing the dream: Leadership in the 21st century, Training: The Magazine of Human Resource Development, 27(5), 44-46.

12. Bennis, W. G. \& Nanus, B. (1985) Leaders: The Strategies for Taking Charge. New York: Harper \& Row.

13. Bryant, M.A. (1990) Relationship Between Nurse Managers Perceived Transformational versus Transactional Leadership Styles and Staff Nurse Turnover, Unpublished master's thesis, University of Arkon, Akron, $\mathrm{OH}$.

14. Bryman, A. (1992) Charisma and Leadership in Organizations. London: Sage.

15. Collins, J.C. \& Porras J.I. (1994) Built to Last: Successful Habits of Visionary Companies. Century: London.

16. Conger, J. A. \& Kanungo, R.N. (1987) Toward a behavioral theory of charismatic leadership in organizational settings, Academy of Management Review, 12, 637-647.

17. Conger, J. A. (1991) Inspiring others: The language of leadership, Academy of Management Executive, $5(1), 31-45$.

18. Conger, J.A. (1989) The Charismatic Leader: Beyond The Mystique of Exceptional Leadership. San Francisco: Jossey-Bass.

19. Curphy, G.J. (1990) An Empirical Study of Bass' (1985) Theory of Transformational and Transactional Leadership, Unpublished Doctoral Dissertation, The University of Minnesota.

20. Davis, S. \& Meyer, C. (1998) Blur: The Speed of Change in the Connected Economy. San Francisco: Addison-Wesley.

21. Doz, Y.L. \& Prahalad, C.K. (1987) A process model of strategic redirection in large complex firms: The case of multinational corporations, in: Pettigrew, A. (Ed.) The Management of Strategic Change, pp 63-88. Oxford, England: Basil Blackwell.

22. Drath, W. H. (1998) Approaching the Future of Leadership Development. Greensboro, NC: Center for Creative Leadership.

23. Dvir, T., Kass, N. \& Shamir, B. (2004) The emotional bond: Vision and organizational commitment among high-tech employees, Journal of Organizational Change Management, 17(2), 126-143.

24. Gove, P. B. \& Webster, M. (1993) Webster's Third New International Dictionary. Springfield, MA: Merriam-Webster Inc..

25. Hallinger, P. \& Heck, R. (2002) What do you call people with visions? The role of vision, mission and goals in school leadership and improvement, in: Leithwood, K., Hallinger, P. \& Colleagues (Eds.) The Handbook of Educational Leadership and Administration, pp 9-40. Dordrecht: Kluwer.

26. Hamburger, Y. A. (2000) Mathematical leadership vision, Journal of Psychology, 134(6), 601-611.

27. Hamel, G. \& Prahalad, C.K. (1989) Strategic intent, Harvard Business Review, 89(3), 63-76.

28. Handy, C. (2002) What is a business for?, Harvard Business Review, 80(12), 48-55.

29. Hay, M. \& Williamson, P. (1997) Good strategy: The view from below, Long Range Planning, 30, 651664. 
30. House, R.J., Spangler, W.D. \& Woycke, J. (1991) Personality and charisma in the U.S. presidency: A psychological theory of leadership effectiveness, Administrative Science Quarterly, 36, 364-396.

31. Howell, J.M. \& Frost, P.J. (1989) A laboratory study of charismatic leadership, Organizational Behavior and Human Decision Processes, 43(2), 243-269.

32. Humphreys, J. (2004) The vision thing, MIT Sloan Management Review, Spring, 96.

33. Hunt, J.G. (1991) Leadership: A New Synthesis. Newbury Park, CA: Sage.

34. Jacobs, T. O. \& Jaques, E. (1990) Military executive leadership, in Clark, K.E. \& Clark, M.B. (Eds.) Measures of Leadership, pp 281-295. West Orange, NJ: Leadership Library of America.

35. Kantabutra, S. (2003) An Empirical Examination of Relationships between Customer and Staff Satisfaction in Retail Apparel Stores in Sydney, Australia, Unpublished Doctoral Dissertation, Macquarie Graduate School of Management, Macquarie University, Sydney.

36. Kantabutra, S. (2005a) Improving public school performance through vision-based leadership, Asia Pacific Eduction Review, 6(2), 122-134.

37. Kantabutra, S. (2005b) Leadership for sustainable organizations: A proposed model, Sasin Journal of Management, 11(1), 59-72.

38. Kantabutra, S. (2006) Relating vision-based leadership to sustainable business performance: A Thai perspective, Kravis Institute Leadership Review, 6(Spring), 37-53.

39. Kantabutra, S. \& Avery, G.C. (2005) Essence of shared vision: Empirical investigation, New Zealand Journal of Human Resources Management, 5, 1-28.

40. Kirkpatrick, S.A. (1992) Decomposing Charismatic Leadership: The Effects of Leader Content and Process on Follower Performance, Attitudes, and Perceptions, Unpublished Doctoral Dissertation, University of Maryland, College Park.

41. Kirkpatrick, S. \& Locke, E. (1996) Direct and indirect effects of three core charismatic leadership components on performance and attitudes, Journal of Applied Psychology, 84(1), 36-51.

42. Kotter, J. P. (1999) What Leaders Really Do. Cambridge, MA: Harvard Business Review Books.

43. Kotter, J. P. (1997) Leading by vision and strategy, Executive Excellence, 14(10), 15-16.

44. Kotter, J.P. (1990) A Force for Change: How Leadership Differs from Management. New York: Free Press.

45. Kouzes, J.M. \& Posner, B.Z. (1987) The Leadership Challenge: How To Get Extraordinary Thing Done in Organizations. San Francisco: Jossey-Bass.

46. Larwood, L., Falbe, C. M., Kriger, M, R. \& Miesling, P. (1995) Structure and meaning of organization vision, Academy of Management Journal, 85, 740-769.

47. Levin, M.L. (2000) Vision revisited, The Journal of Applied Behavioral Science, 36, 91-107.

48. Lipton, M. (1996) Demystifying the development of an organizational vision, Sloan Management Review, 37(4), 83-91.

49. Locke, E. A., Kirkpatrick, S., Wheeler, J.K., Schneider, J., Niles, K., Goldstein, H., Welsh \& Chah, D.O. (1991) The Essence of Leadership. New York: Lexington Books.

50. Lucey, J., Bateman, N. \& Hines, P. (2005) Why major lean transitions have not been sustained, Management Services, 49(2), 9-13.

51. Maccoby, M. (1981) The Leader. New York: Simon \& Schuster.

52. McDaniel, C. \& Wolf, G.A. (1992) Transformational leadership in nursing service, Journal of Nursing Administration, 22(2), 60-65.

53. Mumford, M.D.\& Strange, J.M. (2005) The origins of vision: Effects of reflection, models, and analysis, Leadership Quarterly, 16, 121-148.

54. Nanus, B. (1992) Visionary Leadership: Creating A Compelling Sense of Direction for Your Organization. San Francisco, CA: Jossey-Bass.

55. O'Brien, F. \& Meadows M. (2000) Corporate visioning: A survey of UK practice, Journal of the Operational Research Society, 51, 36-44.

56. Parikh J. \& Neubauer F. (1993) Corporate visioning, in Hussey DE (ed) International Review of Strategic Management 4, pp 105-116. Wiley: Chichester.

57. Pearson, A.E. (1989) Six basics for general managers, Harvard Business Review, 67(4), 94-101.

58. Peters, T. (1987) Thriving on Chaos. New York: Harper \& Row.

59. Phillips, R.L. \& Hunt, J.G. (1992) Strategic leadership: An introduction, in Phillips, R.L. \& Hunt, J.G. (Eds.) Strategic Leadership: A Multiorganizational-level Perspective, pp 2-14. Westport, CT: Quarum.

60. Puffer, S.M. (1990) Attributes of charismatic leadership: The impact of decision style, outcome, and observer characteristics, Leadership Quarterly, 1(3), 177-192.

61. Quigley, J.V. (1993) Vision: How Leaders Develop It, Share It, and Sustain It. New York: McGraw-Hill. 
62. Rafferty, A.E. \& Griffin, M.G. (2004) Dimensions of transformational leadership: Conceptual and empirical extensions, Leadership Quarterly, 15, 329-354.

63. Raynor, M.E. (1998) That vision thing: Do we need it?, Long Range Planning, 31, 368-276.

64. Robbins, S.R. \& Duncan, R.B. (1988) The role of the CEO and top management in the creation and implementation of strategic vision, in Hambrick, D.C. (Ed.) The Executive Effect: Concepts and Methods for Studying Top Managers, pp 137-162. Greenwich, CT: JAI Press.

65. Roberts, N. (1985) Transforming leadership: A process of collective action, Human Relations, 38, $1023-46$.

66. Roberts, N.C. \& Bradley, R.T. (1988) The limits of charisma, in Conger, J.A. \& Kanungo, R.N. (Eds) Charismatic Leadership: The Elusive Factor in Organizational Effectiveness, pp 253-275. San Francisco: Jossey-Bass.

67. Rynes, S.L., Colbert, A.E. \& Brown, K.G. (2002) HR professionals' beliefs about effective human resource practices: Correspondence between research and practice, Human Resource Management, 41, 149.

68. Sashkin, M. (1988) The visionary leader, in Conger, J.A. \& Kanungo, R.N. (Eds.) Charismatic Leadership: The Elusive Factor in Organizational Effectiveness, pp 122-160. San Francisco: Jossey-Bass.

69. Sashkin, M. (1992) Strategic leadership competencies: An introduction, in Phillips, R.L. \& Hunt, G. (Eds.) Strategic Leadership: A Multiorganization-level Perspective, pp 139-160. Westport, CT: Quorum.

70. Schoemaker, P.J.H. (1992) How to link strategic vision to core capabilities, Sloan Management Review, Fall, 67-81.

71. Seeley, D. S. (1992) Visionary Leaders for Reforming Public Schools, paper presented at the Annual Meeting of the American Educational Research Association, San Francisco, CA.

72. $\quad$ Senge, P.M. (1990) The Fifth Discipline: The Art \& Practice of the Learning Organization. New York: Currency Doubleday.

73. Sims, H.P., Jr. \& Lorenzi, P. (1992) The New Leadership Paradigm: Social Learning and Cognition in Organizations. Newbury Park, CA: Sage.

74. Slater, R. (1993) The New GE: How Jack Welch Revived an American Institution. Homewood, IL: Business One Irwin.

75. Stevenson, B. (1949) The Home Book of Bible Quotations. New York: Harper \& Row.

76. Takala, T. (1998) Plato on leadership, Journal of Business Ethics, 17(7), 785-798.

77. Thomas, H. \& Thomas, D. L. (1959) Living Biographies of Religious Leaders. New York: Garden City Books.

78. Tichy, N.M. \& Devanna, M.A. (1986) The Transformational Leader. New York: Wiley.

79. Van der Heijden K. (1996) Scenarios: The Art of Strategic Conversation. Wiley: Chichester.

80. Vandermerwe, S. (1995) The process of market driven transformation, Long Range Planning, 28(2), 79-91.

81. Viney, J. (1999) Drive: What Makes A Leader in Business and Beyond. London: Bloomsbury Publishing.

82. Wall, B., Solum, R.S. \& Sobol, M.R. (1992) The Visionary Leader. Rocklin, CA: Prima.

83. Wallis, J. (1994) The Soul of Politics: A Practical and Prophetic Vision for Change. New York: Orbis Books.

84. Weber, M. (1947) The Theory of Social and Economic Organizations, translated by Parsons, T. New York: Free Press.

85. Westley, F. \& Mintzberg, H. (1989) Visionary leadership and strategic management, Strategic Management Journal, 10, 17-32.

86. Wheatley, M.J. (1999) Leadership and The New Science: Discovering Order in A Chaotic World, (2 $\left.{ }^{\text {nd }}\right)$. San Francisco: Berrett-Koehler.

87. Williams-Brinkley, R. (1999) Excellence in patient care demands a clear vision in action, Health Care Strategic Management, 17(1), 18-19.

88. Yukl, G.A. \& Van Fleet, D.D. (1982) Cross-situational, multimethod research on military leader effectiveness, Organizational Behavior and Human Performance, 30, 87-108.

89. Zaccaro, S. J. (2001) The Nature of Executive Leadership: A Conceptual and Empirical Analysis of Success. Washington DC, APA Books.

90. Zaccaro, S. J. \& Banks, D. (2004) Leader visioning and adaptability: Bridging the gap between research and practice on developing the ability to manage change, Human Resource Management, 43 (4), 367-380. 